\title{
NECESSIDADE DE CRIMINALIZAR A HOMOFOBIA NO BRASIL: PORVIR DEMOCRÁTICO E INCLUSÃO DAS MINORIAS
}

\section{THE NEED FOR CRIMINALIZING HOMOPHOBIA IN BRAZIL: DEMOCRATIC FUTURE AND INCLUSION OF MINORITIES}

Diogo Bacha e Silva*

\author{
Alexandre Gustavo Melo Franco Bahia ${ }^{* *}$
}

\begin{abstract}
RESUMO: o presente artigo pretende abordar a temática da criminalização da homofobia, especialmente por meio da reflexão em torno da Ação Direta de Inconstitucionalidade por Omissão número 26 e do Mandado de Injunção número 4733, ajuizados perante o Supremo Tribunal Federal e que pretendem instar essa Corte a declarar a condição omissiva em que se encontra o Estado brasileiro em relação às minorias - lésbicas, gays, bissexuais, travestis, transexuais e transgêneros (LGBT) - no que tange à criminalização de condutas discriminatórias que atentam contra seus direitos de liberdade e de igualdade. Para tanto, buscamos demonstrar que o projeto constitucional não é e nem deve ser visto como um projeto fechado a novos sujeitos e novos direitos - o processo de aprendizagem constitucional e a consolidação democrática devem buscar a incorporação de novos sujeitos que, em algum momento, sofrem discriminações.
\end{abstract}

PALAVRAS-CHAVE: Criminalização. Democracia. Homofobia. Omissão inconstitucional. Supremo Tribunal Federal.

ABSTRACT: This article aims to address the issue of criminalization of homophobia, especially through the reflection on the Direct Action of Unconstitutionality by Omission \# 26 and the Writ of Injunction \# 4733, both filed before the Brazilian Supreme Court (STF) and wishing to urge this Court to declare the omissive condition in which is the Brazilian State towards minorities lesbians, gays, bisexuals, travestis, transsexuals and transgenders (LGBT) - regarding the criminalization of discriminatory behaviors that threaten their rights to freedom and equality. Therefore, we demonstrate that the constitutional project is not and should not be seen as a closed project to new subjects and new rights - the process of constitutional learning and democratic consolidation should seek the incorporation of new subjects who, at some point, suffer discrimination.

KEYWORDS: Brazilian Supreme Court. Criminalization. Democracy. Homophobia. Unconstitutional omission.

\footnotetext{
* Mestre em Direito pela FDSM. Professor e Coordenador do Curso de Direito da Faculdade de São Lourenço. Membro do IHJ. Advogado. E-mail: diogobacha@ig.com.br

** Mestre e Doutor em Direito Constitucional pela UFMG. Professor Adjunto da Universidade Federal de Ouro Preto e do IBMEC-BH. Advogado.E-mail: alexprocesso@gmail.com
} 


\section{INTRODUÇÃO}

A consolidação de um projeto democrático envolve, necessariamente, levar a sério o debate de temas que, de uma forma ou de outra, carregam uma profunda desavença moral. A Constituição Federal de 1988, ao promover a abertura democrática, também trouxe uma polarização nos debates políticos. É necessário, no entanto, que os desacordos morais sejam partes da agenda política institucional brasileira.

Há que se compreender, de uma vez por todas, que democracia sem desacordos é ditadura de maioria. É da essência da democracia haver discordância sobre questões fundamentais. Por isso a existência, por exemplo, de partidos políticos, que devem (deveriam) capitanear tais desavenças, polarizar o debate e, a partir de discussões, chegar a consensos ou ao menos a compromissos racionais e intersubjetivamente construídos. Se "partidos não tomam partido” a respeito de questões fraturantes, aí sim temos um grave indício de enfermidade na democracia.

Entender que desacordos morais fazem parte dos debates políticos é também compreender que o projeto constituinte democrático iniciado pela Constituição de 1988 não é, e nem pode ser visto, como ato de fundação de um Estado e uma sociedade em um momento único, que foi finalizado com a entrega da obra da Assembleia Nacional Constituinte (ACKERMAN, 2006). A Constituição de 1988 instaura um “projeto” e é apenas como algo que se projeta para o futuro que se pode falar em legitimidade de uma Constituição. Entendê-la como um "plano fechado" é não compreender, de uma só vez: o papel de uma Constituição; a tensão entre democracia e constitucionalismo; a democracia como “à venir” (MOUFFE, 1994) além do caráter aberto de qualquer norma jurídica, que não "enclausura sentidos/essências”, como se tal fosse possível ou desejável.

A Constituição nada mais faz do que inaugurar uma comunidade política de cidadãos livres e iguais que se destina a possibilitar que os próprios cidadãos se vejam como partícipes de um projeto inacabado de autoconstituição da sociedade e do Estado que está sujeito a um longo processo de aprendizado que corrige a si próprio $^{1}$. A responsabilidade pela condução do projeto autoconstitucional do Estado Constitucional é - e sempre será - nossa mesmo, enquanto cidadãos

\footnotetext{
${ }^{1}$ Essa legitimidade da Constituição a concebe como um processo que mira no futuro (e não exclusivamente no passado, no seu marco de origem) no qual, pois, "a interpretação da história constitucional como um processo de aprendizagem apóia-se numa ideia não trivial segundo a qual as gerações posteriores tomam como ponto de partida as mesmas medidas que tinha sido tomadas pela geração dos fundadores. Hoje em dia, quem carrega seu juízo com a expectativa normativa da inclusão completa, do reconhecimento recíproco, e da expectativa de iguais chances para o uso de iguais direitos tem que tomar como ponto de partida a ideia de que ele pode obter essas medidas de uma apropriação racional da constituição e da história de sua interpretação [...]. Eles têm que supor que todas as gerações precedentes tiveram a mesma intenção de criar a ampliar as bases para uma associação livre de parceiros do direito, que doa a si mesma as leis de que necessita” (HABERMAS, Jürgen. Era das transições. Rio de Janeiro: Tempo Brasileiro, 2003. p. 166).
} 
livres e iguais. Esse dado do aprendizado não poderia estar mais claro na Constituição de 1988, quando a mesma diz, textualmente, no $\S 2^{\circ}$ de seu art. $5^{\circ}$, que: “Os direitos e garantias expressos nesta Constituição não excluem outros decorrentes do regime e dos princípios por ela adotados, ou dos tratados internacionais em que a República Federativa do Brasil seja parte”. Ora, isso nada mais é que o reconhecimento do projeto aberto da Constituição e de que não podemos tomar o "mínimo" ali apontado como se fosse o "máximo”.

\section{CONSTITUIÇÃO E O PORVIR DEMOCRÁTICO: SOBRE A CONSOLIDAÇÃO DO PROJETO DEMOCRÁTICO}

Decerto, o ato fundacional marcado pela Assembleia Constituinte tem um papel importante. Representa, de alguma forma, um novo começo, uma refundação que, nem por isso, apaga o passado histórico (CRUZ, 2008). Há muito mais que o efeito simbólico de um reinício quando, a partir de revoluções políticas, reconhecemos os erros do projeto passado. O problema está justamente quando não passamos pelo processo de aprendizagem em níveis mais profundos do que a “mera” mudança formal de texto constitucional, o que faz com que tradições autoritárias antigas ainda cobrem seu preço nos dias de hoje. Um exemplo disso é a dificuldade que o Brasil tem em punir os responsáveis por torturas e mortes durante a ditadura, tendo o próprio Supremo Tribunal Federal (STF) legitimado tal postura negatória ao entender pela não revisão da Lei de Anistia.

No que nos toca aqui mais especificamente, tradições conservadoras mal disfarçadas de “positivismo jurídico neutro” (pretensamente neutro) ainda rondam as faculdades de direito e as barras dos tribunais. Pior, contribuem para que o Legislativo não tome posição acerca de questões problemáticas, pois se entende que a omissão do legislador em tomar parte é uma forma de “silêncio eloquente” (atrelado ao princípio da "reserva legal”) que resolve tais questões sem ter de resolvê-las e pretende-se que, assim, também os tribunais delas não possam tratar, fazendo-se letra morta do que a Constituição dispõe acerca da “aplicabilidade imediata” dos Direitos Fundamentais (art. $5^{\circ}, \S 2^{\circ}$ ), do Mandado de Injunção (art. $5^{\circ}$, LXXI) e da Ação Direta de Inconstitucionalidade por Omissão (art. 103, $\S 2^{\circ}$ ) e também do compromisso da Constituição em dar prevalência aos Direitos Humanos reconhecidos pelo Brasil como componentes do Ordenamento Jurídico (art. $4^{\mathrm{o}}$, II c/c art. $5^{\circ}, \S \S 2^{\circ}$ e $\left.3^{0}\right)$.

O processo de aprendizagem constitucional leva em consideração que, para construirmos uma sociedade livre, igual e justa, precisamos contar com a participação democrática do maior número possível de indivíduos. Participação democrática esta que não se apoia somente no exercício dos direitos políticos, ativos ou passivos. Implica algo mais profundo do que a simples 
presença física na comunidade política. Significa que a esfera pública deve aceitar, conviver e reconhecer o maior número de concepções de vida boa.

O ato de reconhecer o maior número de projetos de vida boa tem o propósito de construir a nossa própria identidade constitucional. Somente nos reconhecemos como partes de um projeto constituinte quando nos sentimos com autonomia moral suficiente para nos percebermos destinatários e coautores das decisões políticas fundamentais. Essa autonomia moral só é constituída por meio do autorrespeito, entendido como a possibilidade de reconhecimento jurídico de pessoas que partilham com outras de sua coletividade as mesmas propriedades que as colocam no plano discursivo da vontade constitucional (HONNETH, 2003, p. 197).

A corrosão de nossa comunidade política ocorre quando há privação e violação de direitos a determinados indivíduos, como formas de reconhecimento denegado. Esse é um comportamento danoso aos indivíduos lesados que viola, frontalmente, a maneira como eles próprios se enxergam. Por isso, há uma intrínseca relação entre a própria dignidade do indivíduo e o reconhecimento por outros. Somente há o completo respeito se há o reconhecimento por terceiros.

Reconhecimento que não se dá, obviamente, apenas pela aceitação passiva das formas de vida boa. O processo de reconhecimento implica a assunção de que é necessária a inclusão desses projetos de vida boa como inerentes à democracia e à formação da vontade pública. Saber que as concepções são inerentes ao projeto democrático significa incorporá-las à Constituição.

Em face da incorporação dos projetos de vida boa devemos interpretar a Constituição e seus dispositivos a partir de tal norte. Principalmente no que respeita aos direitos fundamentais, a interpretação de seus conteúdos deve abarcar o máximo possível de projetos de vida para que possamos construir uma sociedade livre, igualitária e despida de quaisquer preconceitos.

Não é por outra razão que nossa democracia deve discutir a necessidade de se criminalizar ou não condutas atentatórias contra a orientação sexual e a diversidade de gênero. A primeira tentativa de discussão foi levada a efeito pelo Projeto de Lei 122/2006 da Câmara, que obteve uma clara definição pela criminalização da homofobia e transfobia e das demais discriminações de identidade e gênero. ${ }^{2}$ No entanto, tal projeto de lei encontra-se há muito tempo estagnado no Senado ${ }^{3}$.

A cada nova incorporação de concepções de vidas boas ficam latentes exclusões de outros projetos. Por isso o projeto constitucional de inclusão de novos indivíduos titulares de direitos

\footnotetext{
${ }^{2}$ Originalmente, Projeto de Lei 5003, apresentado na Câmara em 2001 pela Deputada Iara Bernardi (PT/SP) e lá aprovado em 2006, quando seguiu para o Senado e desde então não foi aprovado e nem rejeitado.

${ }^{3} \mathrm{O}$ andamento encontra-se disponível em: <http://www.senado.gov.br/atividade/materia/detalhes.asp?p_cod_mate=796 04>. Acesso em: 30 ago. 2014.
} 
fundamentais deve se manter aberto, como, aliás, determina o art. $5^{\circ}, \S 2^{\circ}$ da CF/88 supramencionado.

Desse modo, ao nos comprometermos com a inclusão dos indivíduos que sofreram historicamente discriminações raciais e estipularmos a obrigatoriedade de o legislador prever como crimes as condutas discriminatórias (art. 5 XLII, CF), por certo não se pretende fechar o elenco de tutela apenas às discriminações sofridas pelos negros e judeus. Uma interpretação que pretenda restringir o âmbito de aplicação do mandado de criminalização é, em verdade, uma interpretação constitucional que omite direitos fundamentais de minorias políticas.

\section{ESTADO DEMOCRÁTICO DE DIREITO: COMPROMISSOS CONSTITUCIONAIS E CONVENCIONAIS DO BRASIL FRENTE À MINORIA LGBT}

Os paradigmas tradicionais de Estado $^{4}$ e a consequente configuração dos direitos fundamentais que os acompanham encontram-se superados, pois incapazes de oferecer respostas idôneas às demandas da atualidade. Tanto o Estado Liberal, com suas Declarações (meramente) formais de Direitos quanto o Estado de Bem-Estar Social - com sua proposta de materialização homogeneizante e burocrática - mostram-se hoje falhos em possibilitar o reconhecimento de grupos minoritários que se autorreconhecem por critérios de cor, raça, procedência nacional, orientação sexual e identidade de gênero, etc. e que demandam o reconhecimento de sua diversidade ou que, de toda sorte, são colocados em situação de subalternidade (como os citados acima, mas também outros, como as mulheres) e, por isso, também precisam que o Estado adote políticas especiais/específicas.

O paradigma do Estado Democrático de Direito, então, coloca-se como possível resposta às dificuldades não solucionadas pelos anteriores, já que toma a diversidade e a crise como componentes normais da democracia e pode oferecer respostas aos atuais "problemas” de desagregação social, hipercomplexidade e lutas por reconhecimento, uma vez que trabalha com a

\footnotetext{
${ }^{4}$ Valemo-nos da noção de paradigma a partir de Thomas Kuhn (In: “A Estrutura das Revoluções Científicas”), o qual salienta a historicidade e descontinuidade do conhecimento científico pela alteração de paradigmas. Transpondo para o Direito, Habermas defende que as diferentes conformações que as ordens jurídicas possuem não se devem apenas à forma como foram consagrados os direitos fundamentais, nelas "se reflejan también paradigmas jurídicos distintos" (HABERMAS, Jürgen. Facticidad y Validez: sobre el derecho y el estado democrático de derecho en términos de teoría del discurso. Madrid: Trotta, 1998. p. 263). Assim, no que tange aos princípios do Estado de Direito e dos Direitos Fundamentais, um paradigma jurídico mostra como aqueles hão de ser compreendidos no interior de uma dada comunidade jurídica. Cf. CARVALHO NETTO, Menelick de. A Contribuição do Direito Administrativo Enfocado da Ótica do Administrado para uma Reflexão acerca dos Fundamentos do Controle de Constitucionalidade das Leis no Brasil: um pequeno exercício de Teoria da Constituição. Revista Fórum Administrativo, Belo Horizonte, n. 1, março 2001, p. 11-20. Cf., ainda, CATTONI DE OLIVEIRA, Marcelo de Andrade. Direito Processual Constitucional. Belo Horizonte: Mandamentos, 2001.
} 
tensão entre democracia (como vontade da maioria) e constitucionalismo (como proteção às minorias), ${ }^{5}$ fundamental para compreendermos o papel do Direito e dos Poderes Públicos na atualidade. $^{6}$

Entre os vários desafios de consolidação do Estado Democrático de Direito destacam-se o reconhecimento do pluralismo e da diversidade. Ao contrário dos paradigmas de Estado anteriores, que pressupunham a homogeneidade social, racial, religiosa, e/ou de padrões “normais” de sexualidade, $^{7}$ o Estado Democrático de Direito toma a heterogeneidade, o pluralismo e a diversidade não apenas como dados, mas como elementos essenciais, justamente para a constituição do Estado e para a garantia e efetividade dos direitos fundamentais. A diversidade cria um espaço que possibilita o debate sobre possíveis soluções aos problemas sociais-políticos-jurídicos de um Estado, e não sobre um problema que deva ser eliminado pela construção da ideia de "um povo homogêneo”. Agora, ao se partir da pluralidade e da diversidade - em vez de desconsiderá-las, como os liberais, ou de tentar eliminá-las, como os defensores do Estado-Providência -, o Estado Democrático de Direito pode lidar melhor com a luta pelo reconhecimento das minorias, luta que envolve igualdade como isonomia (igualdade perante a lei), igualdade como equidade (ou igualdade material) e igualdade como diversidade (que percebe que grupos se autoatribuem traços distintivos e que tais devem ser preservados) ${ }^{8}$. O Estado Democrático de Direito, entendemos, possui melhores

\footnotetext{
${ }^{5}$ Como pontua Menelick: “o constitucionalismo só é efetivamente constitucional se institucionaliza a democracia, o pluralismo, a cidadania de todos, se não o fizer é despotismo, autoritarismo; bem como a democracia só é democracia se impõe limites constitucionais à vontade popular, à vontade da maioria, se assim não for estaremos diante de uma ditadura, do despotismo, do autoritarismo" [CARVALHO NETTO, Menelick de. A Constituição da Europa. In: SAMPAIO, José Adércio Leite (Coord.). Crise e Desafios da Constituição: perspectivas críticas da teoria e das práticas constitucionais brasileiras. Belo Horizonte: Del Rey, 2003. p. 282-283].

${ }^{6}$ Habermas alerta para o perigo que pode significar para uma democracia o momento em que fique claro para o cidadão que eles não "têm chances de ainda terem seus direitos contemplados diante dos tribunais, assim que os eleitores não acreditem que com seu voto possam influenciar em alguma medida a política do governo, [momento em que] o direito terá se transformado num instrumento de controle comportamental e a decisão democrática da maioria em um irrelevante espetáculo de ilusão ou auto-ilusão" (HABERMAS, Jürgen. Uma Conversa sobre Questões de Teoria Política. Entrevista a Mikael Carlehedem e René Gabriels. Revista Novos Estudos CEBRAP, n. 47, mar. 1997. p. 86).

${ }^{7}$ Cf. BAHIA, Alexandre Melo Franco. A interpretação jurídica no Estado democrático de Direito: contribuição a partir da teoria do discurso de Jürgen Habermas. In: CATTONI DE OLIVEIRA, Marcelo A. (Coord.). Jurisdição $e$ hermenêutica constitucional. Belo Horizonte: Mandamentos, 2004. p. 301-357; BAHIA, Alexandre Melo Franco; NUNES, Dierle. O potencial transformador dos direitos privados no constitucionalismo pós-88. Revista dos Tribunais, São Paulo, v. 882, p. 45-60, abr. 2009; AMBROSE, Tom. Heróis e Exílios: ícones gays através dos tempos. Belo Horizonte: Gutenberg, 2011; BORRILLO, Daniel. Homofobia: história e crítica de um preconceito. Belo Horizonte: Autêntica Editora, 2010.

${ }^{8}$ Cf. BAHIA, Alexandre Melo Franco. Proteção à Minoria LGBT no Brasil: avanços e desafios. In: JUBILUT, Liliana L.; BAHIA, Alexandre; MAGALHÃES, José L. Quadros de. Direito à diferença. Volume 2: Aspectos de proteção específica às minorias e aos grupos vulneráveis. São Paulo: Saraiva, 2013a. p. 339-374; BAHIA, Alexandre Melo Franco. A Igualdade é Colorida: por uma nova compreensão do direito de igualdade que reconheça o direito à diversidade. In: ALVES, Cândice Lisbôa; MARCONDES, Thereza Cristina Bohlen Bitencourt (Org.). Liberdade, Igualdade e Fraternidade: 25 anos da Constituição Brasileira. Belo Horizonte: D'Plácido, 2013b. p. 307-327; BAHIA, Alexandre Melo Franco. Fundamentos de teoria da constituição: a dinâmica constitucional no Estado Democrático de Direito brasileiro. In: FIGUEIREDO, Eduardo Henrique Lopes (et. al) (Org.). Constitucionalismo e democracia. Rio de
} 
condições de responder a demandas de minorias, já que fundado nos marcos da pluralidade e da diversidade. Ao não trabalhar com normalidades padronizadas, parece possuir melhores condições de possibilitar mecanismos de reconhecimento da diversidade de orientações sexuais e identidades de gênero e de justificativa da adoção de instrumentos democráticos para coibir a violência (física ou simbólica) que as minorias aqui representadas sofrem diariamente.

Dentro do que se pode chamar de "direito à diversidade", uma questão específica nos chama a atenção e sobre ela será direcionada a pesquisa: trata-se da diversidade de orientações sexuais e identidades de gênero ${ }^{9}$ e a violência decorrente da discriminação e do não-reconhecimento daquelas tidas como “divergentes” - tais questões encontram dificuldades teóricas e práticas em Estados que partem, em sua constituição, de “normalidades” e padrões homogeneizadores.

Particularmente, enfrenta-se, no Brasil, um quadro de segregação social decorrente de discriminações por orientação sexual e identidade de gênero que é agravado pelos sucessivos casos de violência. Apenas para citar alguns dados:

Em 2010, 260 gays, travestis e lésbicas foram assassinados no Brasil. De acordo com um relatório do Grupo Gay da Bahia (GGB) [...] a cada um dia e meio um homossexual brasileiro é morto. Nos últimos cinco anos, houve aumento de $113 \%$ no número de assassinatos de homossexuais. Apenas nos três primeiros meses de 2011 foram 65 assassinatos (JINKINGS, 2011) ${ }^{10}$.

Em 2011 foi criado o “Disque 100” para denúncias de violação aos Direitos Humanos; entre eles, casos de homofobia e transfobia. Quanto a esta, os números não param de crescer, ano a ano, à medida que o serviço vai se tornando mais conhecido, conforme a Secretaria de Direitos Humanos (SEDH, 2011). De qualquer forma, o Poder público apresentou pela primeira vez, em 2012, um relatório sobre homofobia, com dados referentes a 2011 (SEDH, 2012): foram registradas 6.809 denúncias de violações aos direitos humanos da população identificada como Lésbicas, Gays,

Janeiro: Elsevier, 2012. p. 101-126.

9 As expressões “orientação sexual” e "identidade de gênero" podem ser definidas de várias formas e é importante a lembrança de Alexandre Bortolini no sentido de que qualquer tentativa de conceituação e de classificação é sempre redutora de complexidade, já que a sexualidade humana é plural. De toda sorte, apenas para dar os contornos sobre o que se pretende com as expressões acima, pode-se definir orientação sexual como algo que diz respeito à "atração, [a]o desejo sexual e afetivo que uma pessoa sente por outras”. Assim, de forma simplificada podem ser enumeradas as orientações homossexual, heterossexual e bissexual. Já a "identidade de gênero" (ou identidade sexual) "tem a ver com como eu me coloco diante da sociedade, com quais grupos, representações e imagens [com que] eu me identifico e me reconheço” (BORTOLINI, Alexandre (Coord.). Diversidade Sexual na Escola. Rio de Janeiro: Pró-Reitoria de Extensão/UFRJ, 2008. p. 8-9). Classificados os seres humanos sob este aspecto, pode-se falar em: gênero masculino, gênero feminino e transgêneros (travestis e transexuais).

${ }^{10}$ Cf. JINKINGS, Daniella. A cada 36 horas, um homossexual é morto no Brasil. Agência Brasil, Brasília, 4 de abril de 2011. Disponível em: <http://agenciabrasil.ebc.com.br/noticia/2011-04-04/cada-36-horas-um-homossexual-e-morto-nobrasil>. Acesso em: 13 jul. 2014. Cf. também MOTT, Luiz. Causa Mortis: Homofobia - Violação dos Direitos Humanos e Assassinato de Homossexuais no Brasil, 2000 . Disponível em: <http://www.dhnet.org.br/dados/livros/dht/br/mott_homofob/index.html>. Acesso em: 27 maio 2014. 
Bissexuais, Travestis, Transexuais e Transgêneros (LGBT); dentre essas violações, 278 foram homicídios, merecendo destaque o fato de que a maioria dos casos $(61,9 \%)$ de violência contra LGBTs é praticada por pessoas conhecidas da vítima, o que mostra o sentimento de impunidade do ofensor.

Em 2013 divulgou-se que, conforme os dados referentes ao ano de 2012, a violência homofóbica cresceu 166\% em relação a 2011, tendo sido registradas 9.982 violações relacionadas à população LGBT, das quais 310 foram homicídios (BRASIL, 2013a).

Contudo, isso ainda representa uma fração muito pequena da violência que acomete lésbicas, gays, bissexuais, travestis e transexuais, pois, além de outros fatores, o tratamento desses dados é muito recente e desconhecido da maioria dos membros desta comunidade.

O que esses e outros dados mostram é que, de um lado, há um número elevado de casos de violência homofóbica e transfóbica (homotransfóbica) no Brasil, o que pode ser visto tanto a partir de dados oficiais quanto da comparação destes com denúncias de outros casos não reportados, inclusive porque a violência de natureza homotransfóbica possui traços característicos, de sorte que, na maior parte das vezes, a mera descrição do fato já lhe pode caracterizar. De outro lado, há uma subnotificação de dados de violência homotransfóbica no Brasil decorrente: (a) da situação de marginalidade social, econômica e de assistência jurídica especializada de boa parte da minoria LGBT, (b) da descaracterização formal, em muitos casos, da natureza homotransfóbica específica do evento quando a denúncia é feita e, outrossim, (c) decorrente da expectativa de que, mesmo havendo notificação, o(s) agressor(es) não será(ão) punido(s).

Tal constatação viola a Constituição de 1988, justamente aquela chamada de “cidadã” e que tantos avanços vem proporcionando para o constitucionalismo e para a democracia brasileiros; violam-se, e.g., o direito à não-discriminação, que é um objetivo fundamental da República (art. $3^{\circ}$, IV) e o direito de igualdade (art. $5^{\circ}$, caput) - compreendida esta não apenas como isonomia mas também como direito à diversidade ${ }^{11}$. Complementarmente, há vários documentos internacionais (os quais o Brasil recepcionou) prevendo, explícita ou implicitamente, a necessidade de os países preverem mecanismos específicos que possibilitem a prevenção e a adequada repressão à homofobia.

Apesar dos dados e das denúncias e do que o Sistema Jurídico (supra) ordena, não há ações concretas, por parte dos Poderes Públicos, que possam contornar a situação. Falta uma legislação

\footnotetext{
11 “Temos o direito de ser iguais quando a diferença nos inferioriza e o direito de sermos diferentes quando a igualdade nos descaracteriza” [SANTOS, Boaventura de Sousa. Por uma concepção multicultural de direitos humanos. In: SANTOS, Boaventura de Sousa (Org.). Reconhecer para libertar: os caminhos do cosmopolitismo cultural. Rio de Janeiro: Civilização Brasileira, 2003. p. 458].
} 
federal (apesar de haver projeto de lei tramitando há anos no Congresso Nacional - infra) que, a exemplo do combate ao racismo (em suas variadas formas) e à violência doméstica, possa cuidar da questão de forma eficiente e adequada. Abre-se a hipótese, como dito, de que a situação de impunidade em tais casos, somada à vulnerabilidade/marginalidade ${ }^{12}$ social, econômica e jurídica de parte da população LGBT (principalmente dos travestis) gere uma subnotificação aos órgãos oficiais, tanto porque estes não são procurados, como também porque, mesmo quando o são, não há a devida classificação dos fatos como envolvendo homofobia e transfobia, a despeito de tais violências terem traços bem típicos. ${ }^{13}$ A Constituição de 1988 criou um sistema de direitos e garantias que exige que o Estado Brasileiro aja para coibir a violência homofóbica. De igual forma, há documentos sobre Direitos Humanos oriundos de organismos internacionais (como Organização das Nações Unidas - ONU e Organização dos Estados Americanos - OEA) e recepcionados pelo Brasil (e que integram nosso sistema de Direitos Fundamentais, art. $5^{\circ}$, $\S \S 2^{\circ}$ e $3^{\circ}$ - Constituição de 1988) que impõem ao nosso País o dever objetivo de criar mecanismos legais de políticas específicas para prevenir e punir a violência de natureza homofóbica. Dever este que o Brasil tem sistematicamente se recusado a cumprir.

A luta pelo reconhecimento do direito à diversidade relacionado a orientações sexuais e identidades de gênero “divergentes” (direito que o Estado-nação moderno original e o Direito convencionaram como padrão) encontra grandes dificuldades e resistências nos cânones tradicionais do direito (HABERMAS, 2002).

O Estado-nação tradicional impõe uma homogeneidade racial, social e também sexual a seus cidadãos; qualquer “desvio” é rechaçado ${ }^{14}$. Quanto às normas sexuais, podem ser lembradas as normas de caráter sexista baseadas na virgindade e "honestidade" da mulher, presentes tanto em leis civis quanto penais; o mesmo se diga da instituição do casamento (civil), pressuposto como única

\footnotetext{
${ }^{12}$ Cf. SANTOS, 2003, p. 51-73.

${ }^{13}$ Como já notado em Relatório do Comitê de Direitos Humanos da ONU: "Homophobic and transphobic violence has been recorded in all regions. Such violence may be physical (including murder, beatings, kidnappings, rape and sexual assault) or psychological (including threats, coercion and arbitrary deprivations of liberty). These attacks constitute a form of gender-based violence, driven by a desire to punish those seen as defying gender norms. [...] In addition to 'street' violence and other spontaneous attacks in public settings, those perceived as LGBT may be targets of more organized abuse, including by religious extremists, paramilitary groups, neo-Nazis and extreme nationalists. Young LGBT people and those of all ages who are seen to be transgressing social norms are at risk of family and community violence. Lesbians and transgender women are at particular risk because of gender inequality and power relations within families and wider society” (UNITED NATIONS. Human Rights Council. Discriminatory laws and practices and acts of violence against individuals based on their sexual orientation and gender. Disponível em: <http://www2.ohchr.org/english/bodies/hrcouncil/docs/19session/A.HRC.19.41_english.pdf>. Acesso em: 20 jul. 2014).

${ }^{14}$ Sobre isso: HABERMAS, Jürgen. Soberania Popular como procedimento: um conceito normativo de espaço público. Revista Novos Estudos CEBRAP, n. 26, p. 100-13, mar. 1990. p. 100-113, e também HABERMAS, Jürgen. O EstadoNação europeu frente aos desafios da globalização: o passado e o futuro da soberania e da cidadania. Revista Novos Estudos CEBRAP, n. 43, p. 87-101, nov. 1995. p. 87-101.
} 
forma legítima de união e com finalidades de procriação e patrimoniais - sendo que qualquer outro arranjo não deveria ser reconhecido -, isso quando também não lhe eram impostas sanções diretas. Quando a questão é levada para o âmbito de orientações sexuais e identidades de gênero que não se encaixam no modelo de normalidade suposto para o funcionamento dos sistemas do Estado e do Direito, a questão se torna ainda mais complexa, havendo não raro normas que punem formas de exteriorização dessas sexualidades. Falar-se, então, em reconhecimento de direitos, e, inclusive, em punição daqueles que cometem atos de violência contra os “divergentes” constitui-se em um grande desafio.

A violência em razão do gênero ainda é uma realidade mesmo após tantos anos de existência de "Delegacias da Mulher”; prova disso é a própria aprovação da Lei Maria da Penha e, ainda, a necessidade de sua alteração face ao notório descumprimento da mesma.

No Brasil há um quadro tradicional de segregação e de não reconhecimento de orientações sexuais e identidades de gênero minoritárias, o que viola a Constituição de 1988 e seu compromisso com o pluralismo e a inclusão, e mesmo o compromisso face às normas/instituições internacionais de Direitos Humanos.

E qual tem sido a resposta dos "Poderes Constituídos” à questão? No que toca ao Executivo Federal, os Planos Nacionais de Direitos Humanos preveem, desde sua primeira edição, o compromisso com a aprovação de leis favoráveis aos LGBT. Vários órgãos da Administração Pública reconhecem direitos previdenciários (e outros direitos) mesmo sem o Brasil possuir qualquer lei nesse sentido. Há também, como dito, metas postas em: planos plurianuais; planos nacionais de direitos humanos; o Programa "Brasil sem Homofobia" (2004); a I Conferência Nacional LGBT de 2008, seguida da II Conferência em 2011; e a criação do Conselho Nacional de Combate à Discriminação (CNCD) em 2010 (BAHIA, 2010).

A respeito da atuação do Executivo Federal valem, no entanto, duas observações:

a) Apesar de os planejamentos e conferências possuírem pautas e metas claras de anteprojetos de lei em áreas como saúde, educação, trabalho e proteção contra a violência de LGBT, praticamente nenhuma dessas pautas e metas foi transformada em projeto de lei (ou similar) pelo Executivo ou por algum membro de sua base no Congresso Nacional. Mesmo projetos que já tramitavam antes daqueles planos (como o PLC 122/06) não tiveram, como decorrência daqueles planos/conferências, qualquer apoio político-institucional adicional significativo para sua aprovação.

b) Além de não haver progressos na transformação dos planos em ações concretas, também se tem experimentado retrocessos nos últimos anos. Um exemplo foi o "Kit contra a 
Homofobia”, que seria distribuído nas escolas de $2^{\circ}$ grau e que estava sendo confeccionado pelo Ministério da Educação: em 2011 a Presidente da República vetou dito material por pressão de grupos religiosos no Congresso Nacional. ${ }^{15}$ De igual modo, tradicionais programas de combate à aids vêm sofrendo cortes e restrições por pressão da mesma bancada, o que tem sido denunciado por órgãos internacionais como a UNAIDS ${ }^{16}$.

É dizer: de um lado, pouco ou nada foi transformado em projetos de lei que pudessem ser discutidos no Congresso Nacional, e, de outro, tem-se percebido retrocessos em políticas públicas já tradicionais.

Quanto ao Legislativo Federal, vive-se no Brasil uma crise: ele ainda não se deu conta de que, em uma democracia, tem papel de protagonista sobre as questões que afligem a sociedade. Seus membros têm de ter consciência de que representam "setores”, "partes” da comunidade - por isso são organizados em “partidos”. Os parlamentares não são (e nem devem ser) "neutros”. Ao contrário, devem se posicionar quando questões polêmicas são apresentadas. O que se vê, no entanto, é um Parlamento incapaz de lidar com temas “fraturantes”. Partidos políticos que "não tomam partido”. E, observe-se, não é que os partidos no Brasil tenham assumido posições conservadoras no que tange aos direitos de LGBT: eles não assumem qualquer posição.

No Brasil não há uma lei federal sequer a tratar diretamente do tema, a despeito do que diz a Constituição de 1988, isto é, de esta garantir a “não-discriminação” como um direito fundamental

\footnotetext{
15 “Após pressão de religiosos, Dilma suspende produção de 'kit anti-homofobia'. Depois de se reunir nesta quartafeira, 25, com deputados da chamada bancada religiosa, o governo decidiu suspender todas as produções que estavam sendo editadas pelos ministérios da Saúde e da Educação sobre a questão da homofobia. De acordo com o ministro Gilberto Carvalho, da Secretaria-Geral da Presidência da República, a presidenta Dilma Rousseff assistiu vídeos do chamado 'kit anti-homofobia' e não gostou do tom das produções” (grifos nossos). Disponível em: $<$ http://blogs.estadao.com.br/radar-politico/2011/05/25/apos-pressao-de-religiosos-dilma-suspende-producao-de-kithomofobia>. Acesso em: 13 jul. 2014. Noutra oportunidade, quando questionada sobre o veto, a Presidente Dilma afirmou que: "não vai ser permitido a nenhum órgão do governo fazer propaganda de opções sexuais”. Disponível em: <http://g1.globo.com/educacao/noticia/2011/05/governo-nao-fara-propaganda-de-opcao-sexual-diz-dilma-sobrekit.html>. Acesso em: 13 jul. 2014.

16 "Representante do programa de Aids da ONU critica governo por ceder a pressões de grupos religiosos. $\mathrm{O}$ representante da Unaids no Brasil, Pedro Chequer, criticou hoje o governo da presidente Dilma Rousseff, por ceder a pressões de grupos religiosos conservadores em sua política de combate à epidemia de Aids. Ele não falou diretamente em denominações religiosas, mas disse que o governo acaba 'violando direitos' à medida que cede a pressões de 'minorias organizadas'. Em seguida lembrou o episódio, ocorrido em fevereiro, quando o Ministério da Saúde deixou de veicular na TV o vídeo de uma propaganda destinada a jovens gays, estimulando o uso de preservativos [...]” (grifos nossos). Disponível em: <http://blogs.estadao.com.br/roldao-arruda/representante-do-programa-de-aids-da-onu-criticagoverno-por-ceder-a-pressoes-de-grupos-religiosos>. Acesso em: 13 jul. 2014. E: "UNAIDS critica suspensão de kit educativo sobre doença. O Coordenador do Programa Conjunto das Nações Unidas sobre HIV/Aids no Brasil (UNAIDS), Pedro Chequer, classificou como um retrocesso a decisão do governo federal de suspender a distribuição de material educativo com mensagens anti-homofobia e de incentivo de uso da camisinha. 'Recebemos a notícia com desapontamento e surpresa. Esperamos que a decisão seja revista’, afirmou [...]”. Disponível em: <http://noticias.uol.com.br/saude/ultimas-noticias/estado/2013/03/18/unaids-critica-suspensao-de-kit-educativo-sobredoenca.htm>. Acesso em: 13 jul. 2014.
} 
(artigo $3^{\circ}$, IV), o direito de igualdade (artigo $\left.5^{\circ}, \mathrm{I}\right)^{17}$ e, ainda, a despeito de o texto constitucional afirmar expressamente que o rol de direitos ali elencados é aberto e passível de novas incorporações $\left(\right.$ art. $5^{\circ}, \S \S 2^{\circ}$ e $3^{\circ}$ ) e além do fato de já haver resoluções internacionais da OEA e da ONU - infra orientando os países a promoverem políticas de não discriminação contra homossexuais. Verdade seja dita, alguns legislativos (e executivos) municipais e estaduais figuram em posição privilegiada frente ao Federal: talvez a proximidade local, principalmente dos primeiros, permite maior acesso à população, o que tem gerado bons resultados na aprovação de leis e políticas de cidadania esparsas, como o reconhecimento de organizações não governamentais (ONGs) e a promoção de direitos humanos - pense-se, por exemplo, em leis (e políticas) municipais e estaduais de proteção a LGBTs $^{18}$. Contudo, as leis locais existentes podem, no máximo, estabelecer multas para empresas e órgãos do comércio (no limite, cassar a autorização de funcionamento, quando é o caso de a possuírem). Apenas no âmbito federal é que se pode aprovar norma que tipifique criminalmente a discriminação, já que isso é competência exclusiva da União (art. 22, I da Constituição de 1988).

Os vários projetos de lei (e de emenda à Constituição) sobre qualquer tema ligado, ainda que indiretamente, a questões de orientação sexual ou identidade de gênero são colocados de lado. Mas a questão não é que as proposições tenham sido “rejeitadas” em votação. Como mencionado acima, na maior parte dos casos (se não em todos) os membros do Congresso Nacional nem sequer se posicionaram, seja a favor, seja contra. Segue uma pequena lista:

a) o PL 3712/2008, do deputado federal Maurício Rands (PT/PE), que visa incluir “na situação jurídica de dependente, para fins tributários, o companheiro homossexual do contribuinte e a companheira homossexual da contribuinte do Imposto de Renda de Pessoa Física”;

b) O PL 1151/1995, que visa regular a parceria civil entre pessoas do mesmo sexo. Em 1996, houve parecer favorável de uma comissão especial. No entanto, em 2001 o projeto foi retirado de pauta por meio de um acordo de líderes. Verifica-se uma total omissão nos últimos anos, em que pese a apresentação de vários projetos de lei sobre gays.

c) PEC 139/95, 392/2005 e 66/2003, para (re)introduzir no inciso IV do artigo $3^{\circ}$ a proteção contra discriminação por “orientação sexual”,

\footnotetext{
18 Sobre o tema cf. BAHIA, Alexandre Melo Franco; MORAES, Daniel. Discriminação contra minorias sexuais, religião e o constitucionalismo brasileiro pós-88. Revista General de Derecho Constitucional, v. 10, p. 409-31, outubro 2010.

19 A primeira foi arquivada. Quanto às outras duas, de 2005 a 2007 não houve qualquer votação, sendo, então, arquivadas. Desarquivadas ainda em 2007, não tiveram qualquer movimentação até 2011, quando foram novamente arquivadas. O deputado Paulo Pimenta conseguiu desarquivá-las em fevereiro de 2011 e, até agora, não houve qualquer movimentação.
} 
d) Finalmente, o PL 4242/2004, o 3770/2000, o 05/2003 e o 5003/2001 tratavam, em termos gerais, da criminalização da homofobia (e da transfobia), sendo, por isso, reunidos no Projeto de Lei da Câmara (PLC) 122/2006.

O PLC 122/06, originalmente aprovado na Câmara em 23/11/2006 como PL 5003/2001, seguiu para o Senado e, desde então, não conseguiu aprovação, sendo objeto de fortíssima oposição por grupos religiosos representados pela “bancada evangélica” (leia-se, bancada fundamentalista, já que muitos evangélicos não discriminam pessoas por sua orientação sexual ou identidade de gênero). Uma das discussões é que, se o Projeto for aprovado, serão criados “super direitos” para uma minoria ${ }^{20}$.

Os críticos se esquecem, no entanto, que a Lei do Racismo (7716/1989, na qual seria incluído o grupo LGBT) já "protege especialmente” outras minorias discriminadas por raça, cor e, inclusive, religião - é dizer, os mesmos que acusam o movimento LGBT de pretender "privilégio" já são protegidos pela Lei do Racismo que o movimento LGBT quer que lhe proteja de igual forma. O PLC 122 nada mais faz do que buscar estender a proteção, que já existe para negros, judeus, mulheres e outras minorias, às minorias sexuais, sem qualquer privilégio antirrepublicano. ${ }^{21}$

É justamente porque LGBT são uma minoria e justamente porque sofrem "preconceito específico e direcionado” que é necessária uma lei como essa - da mesma forma como foi (e ainda é) necessária uma lei para proteger, contra a discriminação, os negros (e outros), ou, contra a violência doméstica, as mulheres.

O que importa destacar, desde já, é que a violência contra LGBT no País não é uma casualidade: não é que se recorte, dentre os que sofrem violência, aqueles que são pertencentes àquela minoria. Ao contrário, ao se falar em dados de violência homofóbica o que se está fazendo é tratar de uma violência que acontece porque a vítima é membro dessa minoria.

\footnotetext{
${ }^{20}$ Sobre a relação entre argumentação moral-religiosa e homofobia, Rios argumenta: “como uma pessoa religiosa deve aceitar a liberdade de crença e a possibilidade de ateísmo daí decorrente como a melhor forma de garantir sua vivência religiosa, uma pessoa moralmente conservadora pode admitir as garantias de liberdade sexual, a fim de que o Estado, por meio de seus agentes, não tenha a possibilidade de interferir no exercício de sua moralidade”. [...] “[U]m direito democrático da sexualidade implica refutar discursos fundados em premissas religiosas, uma vez que a 'juridicização' dos direitos sexuais e dos direitos reprodutivos na tradição dos direitos humanos coloca esse debate na arena mais ampla do Estado laico e democrático de direito, em sintonia com ideais republicanos” (RIOS, Roger Raupp. A homossexualidade e a discriminação por orientação sexual no direito brasileiro. Revista de Informação Legislativa, a. 38 n. 149 jan./mar. 2001. p. 95).

${ }^{21}$ Nesse sentido, Nucci afirma que descabe falar em analogia prejudicial ao réu, uma vez que não se busca, em processo de equiparação por semelhanças, considerar o “[...] ateu ou o homossexual alguém parecido com o integrante de determinada raça. Ao contrário, está-se negando existir um conceito de raça, válido para definir qualquer agrupamento humano, de forma que racismo ou, se for preferível, a discriminação ou o preconceito de raça é somente uma manifestação de pensamento segregacionista, voltado a dividir os seres humanos, conforme qualquer critério leviano e arbitrariamente eleito, em castas, privilegiando umas em detrimento de outras” (NUCCI, Guilherme de Souza. Leis Penais e Processuais Penais Comentadas. Vol. I. 6a ed., rev. e atualiz. São Paulo: Revista dos Tribunais, 2012. p. 195).
} 
O PLC 122/06, ao contrário do que afirmam seus críticos, não violaria a liberdade de expressão e nem mesmo a liberdade religiosa, constitucionalmente garantidas. Vale dizer, as mais diversas concepções religiosas poderão continuar defendendo que a homossexualidade é “pecado” e que, eventualmente, é conduta que se desvia das suas crenças. Entrementes, a liberdade religiosa não abrange a atribuição à homossexualidade de questões que não estão ligadas à religião, tal como dizer que os homossexuais são pedófilos ${ }^{22}$. É preciso situarmos o que é e quais são os limites da liberdade de expressão e da liberdade religiosa, protegidas pela Convenção Americana dos Direitos Humanos que, em seu art. 13, trata da "liberdade de pensamento e de expressão"23.

A Constituição de 1988, por sua vez, dá contornos ao conteúdo da liberdade de pensamento em seu art. $5^{\circ}$, IV, V, VI e VIII ${ }^{24}$.

Vale lembrar que, de acordo com jurisprudência pacífica do STF, não há direitos absolutos: todos os direitos fundamentais - como a vedação à discriminação (art. $3^{\circ}$, IV), a liberdade de expressão, a liberdade religiosa ou mesmo o direito à vida - estão no mesmo plano do direito de igualdade $^{25}$ e das demais liberdades civis. Vale dizer, a liberdade religiosa só será legitimamente exercida na medida em que considera o outro, o próximo, como portador dos mesmos direitos. Sem a consideração do outro que é tido como diferente, não haverá liberdade, mas hate speech $^{26}$. No caso da diversidade de orientações sexuais e identidades de gênero

\footnotetext{
22 Podemos citar, e.g., textos disponíveis em sites “religiosos” nos quais, para além de questões "teológicas” propriamente ditas, em que são citados textos bíblicos e doutrinários, pode-se apreender outra ordem de "argumentos pseudocientíficos”, como se pode ver em: “[...] o famigerado projeto de lei 122/2006, que cria o crime de delito de opinião no país - uma espécie de ditadura gay no Brasil, pois tal comportamento se tornará incriticável, algo só visto em ditaduras totalitárias” (Disponível em: <www.conscienciacrista.org.br>. Acesso em: 13 jul. 2014. "Nota da Vinacc em resposta à ABGLT”); “O Brasil não é o Irã: o projeto anti-homofobia” (Disponível em: <www.conscienciacrista.org.br>. Acesso em: 13 jul. 2014); e "O 'discreto' apoio da Rede Globo aos projetos antihomofobia” (Disponível em: <www.conscienciacrista.org.br>. Acesso em: 13 jul. 2014). Ver também "explicações” comportamentais dos pais determinando a orientação sexual dos filhos em "Homossexualismo e homossexualidade" (Disponível em: <http://www.ultimato.com.br>. Acesso em: 13 jul. 2014) ou ainda um outro texto em que religiosos se mostram orgulhosamente "homofóbicos", uma vez que a culpa pela epidemia do vírus HIV seria dos homossexuais (“Em Defesa da Homofobia”. Disponível em: <www.juliosevero.com.br>. Acesso em: 13 jul. 2014).

${ }^{23}$ 1. Toda pessoa tem o direito à liberdade de pensamento e de expressão. [...] 2. O exercício do direito previsto no inciso precedente não pode estar sujeito à censura prévia, mas a responsabilidades ulteriores, que devem ser expressamente previstas em lei e que se façam necessárias para assegurar: a) o respeito dos direitos e da reputação das demais pessoas; b) a proteção da segurança nacional, da ordem pública, ou da saúde ou da moral públicas.

${ }^{24} \mathrm{IV}$ - é livre a manifestação do pensamento, sendo vedado o anonimato;

$\mathrm{V}$ - é assegurado o direito de resposta, proporcional ao agravo, além da indenização por dano material, moral ou à imagem;

VI - é inviolável a liberdade de consciência e de crença, sendo assegurado o livre exercício dos cultos religiosos e garantida, na forma da lei, a proteção aos locais de culto e a suas liturgias; [...]

VIII - ninguém será privado de direitos por motivo de crença religiosa ou de convicção filosófica ou política, salvo se as invocar para eximir-se de obrigação legal a todos imposta e recusar-se a cumprir prestação alternativa, fixada em lei;

${ }^{25}$ Direito de igualdade que não se limita a tratamento isonômico em todos os casos, mas implica também tratamento diferenciado (SANTOS, 2003).

${ }^{26}$ Aliás, o debate no STF por ocasião do HC 82424 foi justamente sobre o “conflito” entre "liberdade de expressão” e "racismo": um livro que prega que os judeus querem "dominar o mundo" (qualquer semelhança...) - que se consideram
} 
(homossexualidade, bissexualidade, travestilidade e transexualidade), haverá discurso de ódio sempre que o emitente do discurso não considerar o outro (“objeto da fala”) como igual portador dos mesmos direitos/status que ele. ${ }^{27}$

Em fevereiro/2012, o Tribunal Europeu dos Direitos do Homem (TEDH) confirmou decisão do Judiciário sueco que condenou quatro cidadãos a pagar multa por manifestações homofóbicas. Eles foram condenados por seu discurso de ódio e sob o fundamento dos limites da liberdade de expressão; entre tais limites estaria “a reputação e o direito dos outros” (BAHIA, 2012).

Voltando ao PLC 122/06, percebe-se que já houve várias tentativas de acordo com seus opositores - foi até esboçado um substitutivo -, mas a discussão não avançou; em suas últimas movimentações, foi apensado ao Projeto de Lei sobre Novo Código Penal, o que jogou por terra todos esses anos de tramitação - inclusive pela retirada simultânea, nesse projeto, das menções à “orientação sexual” e à “identidade de gênero”. No final da legislatura passada ele foi desapensado - sem que houvesse qualquer deliberação. Por fim, o Congresso Nacional, em janeiro de 2015, arquivou o PLC 122/06 por falta de tramitação/deliberação no Senado.

Chegamos à atual quadra da história com dados alarmantes sobre violência contra LGBT no Brasil, com pouca repressão a essa violência e sem que, no entanto, o Legislativo se movimente pela aprovação de uma lei que poderia cumprir missão similar à da Lei do Racismo ou à da Lei Maria da Penha.

Os tribunais, por sua vez, parecem ter desenvolvido nos últimos 20 anos uma jurisprudência favorável ao reconhecimento de direitos que envolvem a diversidade de gênero e a diversidade sexual. Contudo, a falta de legislações específicas (não há nenhuma lei federal a regular questões como casamento, união estável, direitos previdenciários ou violência homofóbica) tem feito com que sejam eles, os tribunais, a “criarem” regras a partir dos “princípios” previstos na Constituição de 1988 (CURI; NUNES; BAHIA, 2009). Há limites, no entanto, ao que os Tribunais podem fazer a respeito, e não são raras as vozes que se levantam contra o chamado "ativismo judicial” (STRECK, 2010). Diante da inércia do Legislativo tramitam hoje, inclusive, duas ações no STF requerendo que esse Tribunal de alguma forma preencha o vazio legislativo quanto à proteção

superiores, que atuam no oculto para obter ganhos e que, pois, devemos “tomar cuidado com eles” - um livro assim não é exercício regular da "liberdade de expressão" e sim racismo. Cf. BAHIA, Alexandre Melo Franco. Anti-Semitismo, Tolerância e Valores: anotações sobre o papel do Judiciário e a questão da intolerância a partir do voto do Ministro Celso de Mello no HC 82.424. Revista dos Tribunais, São Paulo, v. 847, p. 443-70, maio 2006.

${ }^{27}$ Nesse sentido também Carbonell, comentando sobre o art. 9º incisos XV e XVIII da : "Ley Federal para Prevenir y Eliminar La Discriminación” (México) de 2003, que traz dispositivos similares (CARBONELL, Miguel. Consideraciones sobre La Ley Federal para Prevenir y Eliminar la Discriminación. In: DE LA TORRE MARTÍNEZ, Carlos. Derecho a la No Discriminación. México: UNAM, 2006. p. 215). 
específica aos LGBT face à violência - são o Mandado de Injunção (MI) 4733 e a Ação Direta de Inconstitucionalidade por Omissão (ADInO) 26, ainda sem data de julgamento (e que serão retomados mais à frente).

No que tange a convenções e documentos internacionais sobre direitos humanos de que o Brasil é signatário (STRECK, 2010) ${ }^{28}$ - ou com os quais comunga - e que, de alguma forma, tratam da igualdade (bem como da proibição de discriminação), podem ser mencionadas:

(I) a Declaração Universal dos Direitos Humanos (DUDH), de 1948, especialmente em seu art. 2 1: “Toda pessoa tem capacidade para gozar os direitos e liberdades estabelecidos nesta Declaração, sem distinção de qualquer espécie, seja de raça, cor, sexo, língua, opinião, ou de outra natureza, origem nacional ou social, riqueza, nascimento ou qualquer outra condição”;

(II) a Convenção Internacional sobre a Eliminação de todas as Formas de Discriminação Racial (1965), parte preambular: “Considerando que todas as pessoas são iguais perante a lei e têm direito a igual proteção contra qualquer discriminação e contra qualquer incitamento à discriminação” e art. $1^{\text {o: }}$ “[...] a expressão ‘discriminação racial’ significará qualquer distinção, exclusão, restrição ou preferência baseada em raça, cor, descendência ou origem nacional ou étnica que tem por objetivo ou efeito anular ou restringir o reconhecimento, gozo ou exercício em um mesmo plano (em igualdade de condição), de direitos humanos e liberdades fundamentais no domínio político, econômico, social, cultural ou em qualquer outro domínio da vida pública”.

A responsabilidade por monitorar o cumprimento dessa Convenção é do Comitê de Eliminação de Discriminação - CERD (art. 14 da Convenção). No Brasil, o Conselho Nacional de Combate à Discriminação e Promoção dos Direitos de Lésbicas, Gays, Bissexuais, Travestis e Transexuais (CNCD/LGBT) acompanha, desde 2001, os casos que tramitam perante aquele Comitê.

(III) O Pacto Internacional sobre Direitos Civis e Políticos, de 1966, em que se lê: “Art. 26. Todas as pessoas são iguais perante a lei e têm direito, sem discriminação alguma, a igual proteção da Lei. A este respeito, a lei deverá proibir qualquer forma de discriminação e garantir a todas as pessoas proteção igual e eficaz contra qualquer discriminação por motivo de raça, cor, sexo, língua, religião, opinião política ou de outra natureza, origem nacional ou social, situação econômica, nascimento ou qualquer outra situação". Em consequência desse Pacto, lembra Roger Rios que "o Comitê de Direitos Humanos das Nações Unidas considerou indevida a discriminação por

\footnotetext{
${ }^{28}$ Vale lembrar que os instrumentos internacionais dos quais o Brasil seja participante integram a ordem jurídica interna como direitos fundamentais (cf. artigo $5^{\circ}$, $\S \S 2^{\circ}$ e $3^{\circ}$ da Constituição de 1988).
} 
orientação sexual no tocante à criminalização de atos sexuais homossexuais, ao examinar o caso Toonen v. Austrália" ${ }^{29}$;

(IV) a Declaração sobre a Eliminação de Todas as Formas de Intolerância e Discriminação Fundadas na Religião ou nas Convicções (Resolução da ONU), de 1981;

(V) o Pacto de San José da Costa Rica, também denominado Convenção Americana de Direitos Humanos.

O Pacto de San José oferece um leque de direitos que cria uma grande rede de proteção dos Direitos Humanos. Para a questão aqui tratada, vale lembrar: Direito ao Reconhecimento da Personalidade Jurídica (art. 3); Direito à Vida (art. 4); Direito à Integridade Física, Psíquica e Moral (art. 5); Direito de Proteção à Honra e à Dignidade (art. 11); Liberdade de Pensamento e de Expressão (art. 13); Direito ao Nome (art. 18); Direito de Igualdade e de Não Discriminação (art. 24).

De igual modo, também constitui direito do cidadão que a rede de proteção ali constituída não seja interpretada/aplicada de forma a (art. 29):

a. permitir a qualquer dos Estados Partes, grupo ou pessoa, suprimir o gozo e exercício dos direitos e liberdades reconhecidos na Convenção ou limitá-los em maior medida do que a nela prevista;

b. limitar o gozo e exercício de qualquer direito ou liberdade que possam ser reconhecidos de acordo com as leis de qualquer dos Estados Partes ou de acordo com outra convenção em que seja parte um dos referidos Estados;

c. excluir outros direitos e garantias que são inerentes ao ser humano ou que decorrem da forma democrática representativa de governo; e

d. excluir ou limitar o efeito que possam produzir a Declaração Americana dos Direitos e Deveres do Homem e outros atos internacionais da mesma natureza.

E não nos esqueçamos de que o Brasil aderiu à competência da Corte Interamericana de Direitos Humanos, e de que a constatação registrada e reconhecida de pesquisas que mostrem o atual estado de violação dos direitos convencionais de uma parcela da população, como os LGBT, legitimaria o procedimento via Comissão Interamericana de Direitos Humanos junto à Corte. Nesse sentido, a OEA já tem indicado à Comissão o monitoramento desse tipo de violência, como veremos abaixo.

Além desses instrumentos, há outros que merecem especial atenção:

\footnotetext{
${ }^{29}$ (RIOS, 2001, p. 287). Como mostra Relatório da ILGA, nessa decisão os membros do Comitê confirmaram "que as legislações que criminalizam relações sexuais consensuais do mesmo sexo estão violando não apenas o direito à privacidade mas também o direito à igualdade face à lei sem qualquer discriminação, contrária aos artigos 17 (1) e 26 do Pacto Internacional de Direitos Civis e Políticos” (OTTOSSON, Daniel. Uma pesquisa mundial sobre legislações que proíbem relações sexuais consensuais entre adultos do mesmo sexo. ILGA - Associação Internacional de Gays e Lésbicas. Homofobia do Estado, maio de 2008. Disponível em: <www.ilga.org>. Acesso em: 2 mar. 2014. p. 4). Lembrando ainda que o Brasil ratificou em 2007 o protocolo facultativo a este Pacto que permite que qualquer cidadão denuncie violações aos direitos civis e políticos diretamente ao Conselho de Direitos Humanos da ONU.
} 
I. a Resolução n. 2435: Direitos Humanos, Orientação Sexual e Identidade de Gênero, aprovada pela Assembleia Geral da OEA em 03 de junho de 2008, “TOMANDO NOTA com preocupação dos atos de violência e das violações aos direitos humanos correlatas perpetradas contra indivíduos, motivados pela orientação sexual e pela identidade de gênero”:

REITERANDO: Que la Declaración Universal de los Derechos Humanos afirma que todos los seres humanos nacen libres e iguales en dignidad y derechos, y que toda persona tiene todos los derechos y libertades proclamados en esta Declaración, sin distinción alguna de raza, color, sexo, idioma, religión, opinión política o de cualquier otra índole, origen nacional o social, posición económica, nacimiento o cualquier otra condición; [...]

CONSIDERANDO que la Carta de la Organización de los Estados Americanos proclama que la misión histórica de América es ofrecer al hombre una tierra de libertad y un ámbito favorable para el desarrollo de su personalidad y la realización de sus justas aspiraciones; REAFIRMANDO los principios de universalidad, indivisibilidad e interdependencia de los derechos humanos.

A partir disso, declarou:

\section{RESOLVE:}

1. Expressar preocupação pelos atos de violência e pelas violações aos direitos humanos correlatas, motivados pela orientação sexual e pela identidade de gênero.

2. Encarregar a Comissão de Assuntos Jurídicos e Políticos [...] de incluir em sua agenda [...] o tema 'Direitos humanos, orientação sexual e identidade de gênero'.

Desde 2008 há uma sequência anual de Resoluções da OEA condenando a discriminação por orientação sexual e identidade de gênero nos países-membros e a eles convocando para que adotem políticas especiais para a coibição e/ou investigação e punição dos responsáveis.

Na reunião de 2009, a Assembleia Geral aprovou a Resolução $2504^{30}$. O mesmo ocorreu em 2010, com a aprovação da Resolução 2600, em 2011, com a Resolução 2653, ${ }^{31}$ em 2012, com a Resolução 2721, e em 2013, com a Resolução 2807, cada uma delas reiterando o disposto anteriormente sobre a proteção necessária à minoria LGBT e insistindo na urgência da adoção, pelos Estados-membros, de medidas específicas nesse sentido.

\footnotetext{
${ }^{30}$ RESUELVE:

1. Condenar los actos de violencia y las violaciones de derechos humanos relacionadas, perpetrados contra individuos a causa de su orientación sexual e identidad de género.

2. Instar a los Estados a asegurar que se investiguen los actos de violencia y las violaciones de derechos humanos perpetrados contra individuos a causa de su orientación sexual e identidad de género, y que los responsables enfrenten las consecuencias ante la justicia.

3. Instar a los Estados a asegurar una protección adecuada de los defensores de derechos humanos que trabajan en temas relacionados con los actos de violencia y violaciones de los derechos humanos perpetrados contra individuos a causa de su orientación sexual e identidad de género

${ }^{31}$ A partir disso a Comissão Interamericana de Direitos Humanos criou uma Unidad para los derechos de las personas LGBTI. No $2^{\circ}$ Informe sobre a Situação dos Defensores de Direitos Humanos na América (31/12/2011), a Comissão Interamericana dedicou um capítulo específico ao problema dos defensores dos direitos LGBT (§§ 325 e ss.).
} 
Não nos esqueçamos da Corte Interamericana de Direitos Humanos, a qual já condenou o Chile por discriminação motivada por orientação sexual - Sentença de 24/02/2012, Caso Atala Riffo e Filhas vs. Chile ${ }^{32}$.

II. Na 43 ${ }^{\mathrm{a}}$ Assembleia Geral da Organização dos Estados Americanos (OEA), na cidade de Antigua (Guatemala), foram aprovados, em 05 de junho de 2013, os textos da "Convenção Interamericana contra o Racismo, a Discriminação Racial e Formas Conexas de Intolerância” e da “Convenção Interamericana contra Toda Forma de Discriminação e Intolerância”, nos quais se verifica a inclusão, pela primeira vez em uma convenção da OEA, do conceito de orientação sexual entre as minorias protegidas. Em consonância com o que propomos neste trabalho, esse conceito não faz diferenciação entre o racismo étnico e a discriminação homofóbica (e, presumivelmente/por analogia, também a transfóbica) ${ }^{33}$.

III. Ainda em 2008 foi aprovada uma declaração da ONU condenando violações dos direitos humanos com base na orientação sexual e na identidade de gênero. Na Declaração A/63/635, de 22 de dezembro de 2008 - (ONU, 2008) os Estados condenaram

as violações de direitos humanos baseadas na orientação sexual ou na identidade de gênero onde quer que tenham lugar [...]. Urgimos com os Estados a tomarem todas as medidas necessárias, em particular as legislativas ou administrativas, para assegurar que a orientação sexual ou identidade de gênero não possam ser, sob qualquer circunstância, à base de sanções penais, em particular execuções, prisões ou detenção.

IV. Em 17/11/2011 o Conselho de Direitos Humanos da ONU, em seu Informe Anual, publicou o documento Leis e práticas discriminatórias e atos de violência contra indivíduos baseados em sua orientação sexual e identidade de gênero ${ }^{34}$.

Nele se reafirmam os princípios da universalidade (dos direitos humanos), da igualdade e da não-discriminação, que deixam claro que leis, ações ou omissões governamentais contra os

\footnotetext{
${ }^{32}$ No âmbito da Corte Europeia de Direitos Humanos há várias decisões garantindo o direito à livre orientação sexual e a vedação à discriminação: Dudgeon v. United Kingdom (1981); Norris v. Ireland (1991); Modinos v. Cyprus (1993); Salgueiro da Silva Mouta v. Portugal (1999); Smith and Grady v. United Kingdom (1999); Goodwin v. United Kingdom (2002); Van Kuck v. Germany (2003); Karner v. Austria (2003); L. and V. v. Austria (2003).

${ }^{33}$ No texto destaca-se: "[que] A discriminação pode basear-se em [...] orientação sexual [...]. [O reconhecimento do] dever de se adotarem medidas nacionais e regionais para promover e incentivar o respeito e a observância dos direitos humanos e das liberdades fundamentais de todos os indivíduos e grupos sujeitos à sua jurisdição, sem distinção por motivo de [...] orientação sexual [...]. [O convencimento] de que determinadas pessoas e grupos vivenciam formas múltiplas ou extremas de discriminação e intolerância, motivadas por uma combinação de fatores como gênero, idade, orientação sexual [...]. [A consideração de] que a experiência individual e coletiva de discriminação e intolerância deve ser levada em conta para combater a exclusão e a marginalização com base em gênero, idade, orientação sexual [...]. [A afirmação que estão] ALARMADOS com o aumento dos crimes de ódio motivados por [...] orientação sexual [...]”.

${ }^{34}$ Trata-se de um estudo que teve como finalidade: "documenting discriminatory laws and practices and acts of violence against individuals based on their sexual orientation and gender identity, and how international human rights law can be used to end violence and related human rights violations based on sexual orientation and gender identity" (Disponível em: <http://www2.ohchr.org/english/bodies/hrcouncil/docs/19session/A.HRC.19.41_english.pdf >. Acesso em: 13 jul. 2014).
} 
LGBT configurariam violação da DUDH e documentos correlatos. São listadas várias formas de violência (física e simbólica) e discriminação perpetradas contra LGBT no mundo e, ao final, são feitas Recomendações aos Estados-parte - praticamente todas “ainda” não são cumpridas no Brasil até os dias de hoje $\mathrm{e}^{35}$.

V. Mais recentemente, a ONU, por meio do Alto Comissariado das Nações Unidas para os Direitos Humanos, publicou, no dia 13 de setembro de 2012, o estudo Born Free and Equal ${ }^{36}$, que estipula obrigações legais para os Estados-parte para proteção dos LGBT.

Por todo o exposto, fica clara a situação de omissão do Estado brasileiro em criminalizar a homofobia, bem como em criar mecanismos eficientes de investigação e, de todo modo, de proteção à minoria LGBT.

\section{A AÇÃO DIRETA DE INCONSTITUCIONALIDADE POR OMISSÃO 26 E 0 MANDADO DE INJUNÇÃO 4733}

A Ação Direta de Inconstitucionalidade por Omissão (ADInO) tombada com o número 26 foi intentada pelo Partido Popular Socialista (PPS). Indubitável que, nos termos do art. 12-A da Lei 9.868/99, os partidos políticos configuram-se como entes legitimados para a propositura de ação direta de inconstitucionalidade por omissão. Ademais, os partidos políticos, enquanto entes essenciais à própria democracia, têm legitimidade universal e irrestrita para a propositura de ações que visem a proteger a normatividade constitucional, prescindindo da demonstração do requisito processual da pertinência temática ${ }^{37}$. De qualquer sorte, essa ação direta de inconstitucionalidade

\footnotetext{
35 “(a) Investigate promptly all reported killings and other serious incidents of violence perpetrated against individuals because of their actual or perceived sexual orientation or gender identity, whether carried out in public or in private by State or non-State actors, and hold perpetrators accountable, and establish systems for the recording and reporting of such incidents; [...] (e) Enact comprehensive anti-discrimination legislation that includes discrimination on grounds of sexual orientation and gender identity among prohibited grounds and recognizes intersecting forms of discrimination; ensure that combating discrimination on grounds of sexual orientation and gender identity is included in the mandates of national human rights institutions [...]; (g) Implement appropriate sensitization and training programmes for police, prison officers, border guards, immigration officers and other law enforcement personnel, and support public information campaigns to counter homophobia and transphobia among the general public and targeted anti-homophobia campaigns in schools; (h) Facilitate legal recognition of the preferred gender of transgender persons and establish arrangements to permit relevant identity documents to be reissued reflecting preferred gender and name, without infringements of other human rights”.

${ }^{36}$ Disponível em: <http://www.ohchr.org/Documents/Publications/BornFreeAndEqualLowRes.pdf $>$. Acesso em: 13 jul. 2014.

${ }^{37}$ A esse respeito, o julgamento da ADI 1096/RS, rel. Min. Celso de Mello, DJ 22-09-1995: “[...] Os Partidos Políticos com representação no Congresso Nacional acham-se incluídos, para efeito de ativação da jurisdição constitucional concentrada do Supremo Tribunal Federal, no rol daqueles que possuem legitimação ativa universal, gozando, em consequência, da ampla prerrogativa de impugnarem qualquer ato normativo do Poder Público, independentemente de seu conteúdo material. A posição institucional dos Partidos Políticos no sistema consagrado pela Constituição do Brasil confere-lhes o poder-dever de, mediante instauração do controle abstrato de constitucionalidade perante o STF, zelarem tanto pela preservação da supremacia normativa da Carta Politica quanto pela defesa da integridade jurídica do
} 
por omissão tem como fundamento, basicamente, a omissão dos poderes públicos em criminalizar a homofobia e a transfobia, como espécies do gênero racismo.

No julgamento do HC 82.424/RS, em que se discutia se as manifestações antissemitas constituíam ou não crime de racismo, o Supremo Tribunal Federal tomou como razão de decidir (ratio decidendi) o fato de que a divisão da espécie humana em raças é realizada por meio de um processo eminentemente político-social, não havendo que se falar em divisão biológica dos seres humanos. O crime de racismo, portanto, tem um cunho sociopolítico no qual o bem jurídico tutelado são todas as manifestações de inferioridade de um grupo de indivíduos a outro grupo. Manifestações essas que são motivadas pelas mais diversas formas de discriminação em virtude de origem étnica, religiosa, confessional, antropológica, biológica. Em verdade, conforme se recolhe do voto do ministro Celso de Mello no julgamento do HC 82.424/RS, o racismo tutela o vínculo comum da espécie humana: "Sem qualquer hierarquia ou distinção de origem, de raça, de orientação confessional ou de fortuna, somos todos pessoas, essencialmente dotadas de igual dignidade e impregnadas de razão e consciência, identificadas pelo vínculo comum que nos projeta, em unidade solidária, na dimensão incindível do gênero humano”. À época escrevemos nesse sentido, tomando, como ponto de partida, o voto do min. Celso de Mello nesse caso:

\begin{abstract}
[O] fato de não se poder falar em tais hierarquias (ou mesmo na existência de diferentes “raças humanas”) não impossibilita a existência do crime de racismo, que ocorrerá justamente pela afirmação irracional (e psicologicamente desviante) da superioridade de um grupo sobre outro; independentemente do "nome" que se usar para denominar o critério de diferenciação preconceituosa: raça, sexo, orientação sexual, religião, nacionalidade, time de futebol, etc. Desde que usados num discurso intolerante e fundamentalista [...], deverão ser tidos como atos criminosos. [...] Em princípio, todas as vezes que diferenças étnicas, de cor, de religião, de orientação sexual, etc., forem usadas para que se estabeleçam distinções em que um grupo aparece superprivilegiado e/ou outro fica sub-privilegiado - estaremos diante do crime de racismo. O conceito de racismo é usado, pois, a partir de parâmetros sociais e culturais para fins de controle ideológico, de dominação política e de subjugação social (BAHIA, 2006, p. 448-9).
\end{abstract}

ordenamento consubstanciado na Lei Fundamental da República. A essencialidade dos partidos políticos, no Estado de Direito, tanto mais se acentua quando se tem em consideração que representam eles um instrumento decisivo na concretização do princípio democrático e exprimem, na perspectiva do contexto histórico que conduziu a sua formação e institucionalização, um dos meios fundamentais no processo de legitimação do poder estatal, na exata medida em que o Povo - fonte de que emana a soberania nacional - tem, nessas agremiações, o veículo necessário ao desempenho das funções de regência política do Estado. O reconhecimento da legitimidade ativa das agremiações partidárias para a instauração do controle normativo abstrato, sem as restrições decorrentes do vínculo de pertinência temática, constitui natural derivação da própria natureza e dos fins institucionais que justificam a existência, em nosso sistema normativo, dos Partidos Políticos. A jurisprudência do Supremo Tribunal Federal erigiu o vínculo de pertinência temática à condição objetiva de requisito qualificador da própria legitimidade ativa ad causam do Autor, somente naquelas hipóteses de ação direta ajuizada por confederações sindicais, por entidades de classe de âmbito nacional, por Mesas das Assembleias Legislativas estaduais ou da Câmara Legislativa do Distrito Federal e, finalmente, por Governadores dos Estados-membros e do Distrito Federal. Precedentes. [...]”. 
Nessa medida, o grupo LGBT, formado por aqueles que têm orientação sexual e/ou identidade de gênero diversas do heterossexismo, constituem um grupo “racial” vulnerável, já que a heterossexualidade seria a única opção aceitável, gerando discriminações e intolerância para a minoria. Dessa forma, e considerando que o comando normativo do art. 5º XLII da CF/88 é um mandamento de criminalização para os Poderes Públicos, é imperioso que o Poder Legislativo edite normas criminalizando a homofobia e a transfobia. ${ }^{38}$ De qualquer sorte, mesmo não sendo considerado caso de racismo, os atos e agressões homofóbicos e transfóbicos são um atentado, motivado apenas pela orientação sexual distinta, aos direitos e liberdades fundamentais do grupo LGBT. A norma do art. 5 XLI da CF/88 determina que os Poderes Públicos reprimam e protejam as liberdades fundamentais, constituindo-se também em um mandamento implícito de criminalização, haja vista que o que temos hoje é um estado de "proteção deficiente”39, já que as normas de criminalização de violências não têm, em geral, conseguido alcançar a diminuição dessa violência - da mesma forma que essas mesmas normas não conseguiam coibir/punir de forma eficaz a violência contra mulheres e, por isso, foi necessária a aprovação da Lei Maria da Penha.

Os mandados de criminalização, expostos na Constituição Federal, exprimem, na verdade, uma característica do garantismo positivo, isto é, visam a obrigar o Estado a ofertar aos cidadãos a proteção a bens jurídicos essenciais. A não efetivação da obrigação de criminalizar, quando o mandado de criminalização decorre da própria Constituição, incide em inconstitucionalidade por omissão. Ora, a homofobia e a transfobia ferem de morte bens jurídicos da mais alta relevância que nossa comunidade política elegeu como norte de toda a sociedade, quais sejam, a própria dignidade humana, a integridade física e moral, a vida, etc., na medida em que impõem a superioridade de um grupo sobre outro apenas pela orientação sexual ${ }^{40}$.

Sabe-se que não há norma jurídico-penal que criminalize de forma específica as agressões e atentados contra a população LGBT. A ausência de norma criminalizadora especial, ${ }^{41}$ ou, pelo menos, o fato de que nossa legislação não prevê qualquer agravante ou qualificadora quando um

\footnotetext{
${ }^{38}$ Conforme bem define a petição inicial, "homofobia é o preconceito e/ou a discriminação contra homossexuais e bissexuais, ao passo que transfobia é o preconceito e/ou a discriminação contra travestis, transexuais e transgêneros em geral".

39 Sobre o tema cf. VIANA, Thiago G. A inefetividade da Lei Caó: uma tragédia anunciada? In: CRUZ, André Gonzalez (Org.). Direito criminal contemporâneo. Brasília: Kiron, 2012. p. 109-132.

${ }^{40}$ Nesse sentido vale a pena a lembrança de trecho de um voto do min. Gilmar Mendes na ADIn 3112, mencionado na petição que deu origem à $\mathrm{ADInO} 26$ : "os mandados constitucionais de criminalização atuam como limitações à liberdade de configuração do legislador penal e impõem a instituição de um sistema de proteção por meio de normas penais. [...] Ao lado dessa idéia de mandados de criminalização expressos, convém observar que configura prática corriqueira na ordem jurídica a concretização de deveres de proteção mediante a criminalização de condutas. Outras vezes cogita-se mesmo de mandados de criminalização implícitos, tendo em vista uma ordem de valores estabelecida pela Constituição. Assim, levando-se em conta o dever de proteção e a proibição de uma proteção deficiente ou insuficiente (Untermassverbot), cumpriria ao legislador estatuir o sistema de proteção constitucional-penal adequado".

${ }^{41}$ Como existe nos EUA, Noruega, Reino Unido, México, Colômbia e Chile.
} 
crime é praticado por razão homofóbica ou transfóbica, ${ }^{42}$ coloca em estado omissivo os Poderes Públicos que têm a missão de efetivar a própria Constituição.

Com esses fundamentos jurídicos, a Ação Direta de Inconstitucionalidade por Omissão número 26 pretende: a) que seja a homofobia e a transfobia enquadradas no conceito de racismo (art. 5 XLII da CF/88) ou, ainda, subsidiariamente, reconhecê-las como atos atentatórios a direitos e liberdade fundamentais (art. 5 ${ }^{\circ}$ XLI da CF/88). Qualquer dessas duas normas constitucionais plasmam um dever de criminalização e proteção por parte do Estado; b) então, que se reconheça o estado inconstitucional de mora do Congresso Nacional em aprovar legislação que criminalize de forma específica a homofobia e a transfobia, já que decorridos mais de 25 (vinte e cinco) anos da promulgação da Constituição Federal e considerando que o PLC 122/2006 encontra-se há mais de 13 (treze) $a_{n o s}{ }^{43}$ em discussão sem ser aprovado; c) que seja fixado prazo razoável para que o Congresso Nacional edite a norma criminalizadora específica; d) não ocorrendo a promulgação da norma no prazo fixado pelo Supremo Tribunal Federal ou caso este entenda tal prazo desnecessário, requerer que o STF realize a troca de sujeitos e exerça atividade legislativa atípica, para considerar como crime todas as formas de homofobia e transfobia; e) a fixação da responsabilidade civil do Estado, inclusive dos parlamentares que se omitirem, ante a responsabilidade objetiva do art. 37, $\S 6^{\circ}$ da CF/88, para todos aqueles que forem vítimas de agressões e violência homofóbica e transfóbica, inclusive quanto a fatos pretéritos, ou, subsidiariamente, a partir da constatação da omissão inconstitucional; f) subsidiariamente, a ação pede que, caso não se entenda cabível a equiparação ao racismo ou a previsão precária do crime pelo STF, que, pelo menos, o STF reconheça o estado inconstitucional de mora objetiva do Congresso Nacional e que o mesmo seja comunicado.

O Mandado de Injunção 4733 foi ajuizado pela Associação Brasileira de Gays, Lésbicas, Bissexuais, Travestis e Transexuais (ABGLT). Cuida-se, pois, de uma associação civil sem fins lucrativos cujo objetivo é a promoção, proteção e defesa dos direitos inerentes aos citados grupos de indivíduos e que promove o Mandado de Injunção na defesa de direitos coletivos perante o Supremo Tribunal Federal ${ }^{44}$.

\footnotetext{
${ }^{42}$ Como ocorre em alguns países, como Portugal e Albânia.

${ }^{43}$ O Projeto original, PL 5003, foi apresentado em agosto de 2001.

44 Desde há muito o STF tem admitido a impetração de mandado de injunção coletivo face à analogia com a norma constitucional do art. 50, LXX que permite o ajuizamento de mandado de segurança coletivo (STF, MI 361/RJ, rel. Min. Néri da Silveira, j. 08/04/1994). Dessa forma, há um completo sistema processual de proteção contra a ofensa a direitos fundamentais, do qual se ressalta que há, contra a ação ou a omissão, em forma individual ou coletiva, garantias processuais disponíveis ao cidadão.
} 
Segue, em linhas gerais, a mesma pretensão veiculada na Ação Direta de Inconstitucionalidade por Omissão, inclusive com os mesmos pedidos veiculados. No entanto, o fundamento do pedido é de que é necessária a criminalização da homofobia e da transfobia, já que tais condutas afetam a possibilidade de as minorias, de orientação sexual e identidade de gênero “diversas”, usufruírem de forma plena o direito de conduzirem uma vida tranquila, o direito à orientação sexual diversa e à livre identidade de gênero, gerando, pois, um grave comprometimento da própria cidadania de uma minoria, que vive em uma situação de insegurança perante a comunidade política.

Os pedidos seguem a mesma lógica da ADInO 26, com a especificidade do pedido de conhecimento do mandado de segurança para a criminalização de condutas quando a omissão inconstitucional dos Poderes Públicos comprometerem ou inviabilizarem o exercício da prerrogativa inerente à nacionalidade, soberania e cidadania.

Segue-se que as duas ações mencionadas pleiteiam e buscam o reconhecimento da mesma questão de fundo, qual seja, a omissão inconstitucional do Congresso Nacional em criminalizar a homofobia e a transfobia. A partir do reconhecimento da omissão inconstitucional seguem-se alguns pedidos, veiculados nas duas ações, que dela são consectários. Por isso, convém não simplificar demasiadamente as ações ajuizadas perante o Supremo Tribunal Federal e ter ciência de que a criminalização da homofobia e da transfobia pelo próprio Supremo Tribunal Federal é um (primeiro) pedido subsidiário, formulado apenas na hipótese de, dado o prazo razoável para o Congresso Nacional, este continuar omisso em sua missão constitucional. Adicionalmente, caso nem o pedido principal nem esse primeiro subsidiário sejam acatados, as ações pedem, por derradeiro, que o STF reconheça a omissão inconstitucional e dela dê ciência formal ao Congresso.

A omissão inconstitucional significa, por exemplo, para J. J. Gomes Canotilho, um não fazer aquilo que estava juridicamente obrigado. Isto é, “a omissão legislativa, para ganhar significado autônomo e relevante, deve conexionar-se com uma exigência constitucional de ação, não bastando o simples dever geral de legislar para dar fundamento a uma omissão inconstitucional” (CANOTILHO, 2003, p. 1033). Também, no mesmo sentido, Carlos Blanco de Morais alude que "existe inconstitucionalidade por omissão quando um órgão público se abstém de editar um acto, cuja prática é exigida pela Constituição, pelo que a inércia do decisor viola um dever constitucional de agir” (MORAIS, 2006, p. 136).

Tem-se, pois, na inconstitucionalidade por omissão, um desvalor jurídico-político sobre uma omissão dos Poderes Públicos. E, bem por isso, não se caracteriza a omissão inconstitucional acerca do dever geral de conformação da ordem constitucional por parte do legislador, mas sim uma 
ordem concreta de legislar emanada de uma norma constitucional - veja-se o inciso XLI e os $\S 1^{\circ}$ e $2^{\circ}$ do art. $5^{\circ}$, combinados com o inciso III do art. $1^{\circ}$, o inciso IV do art. $3^{\circ}$ e o inciso II do art. $4^{0}$, todos da Constituição ${ }^{45}$. Há um não fazer por parte do legislador face à exigência concreta de legislar contida nas normas constitucionais especificamente consideradas (PIOVESAN, 2003, p. 912).

De qualquer sorte, a omissão inconstitucional pode ser deliberadamente parcial, seja mediante a preterição de grupos ou situações que preencham os mesmos requisitos de grupos ou situações contemplados na legislação editada ou, ainda, quando a lei editada não tem a densidade suficiente para contemplar toda a pretensão normativa (CANOTILHO, 2003, p. 1037).

Poder-se-ia objetar que a omissão não é intencional ou que as razões para a não criminalização estariam em concepções minimalistas do Direito Penal e que este não deveria ser utilizado senão como ultima ratio do sistema. Contudo, além do comando constitucional no sentido do dever do legislador em proteger os direitos fundamentais, ainda que com o uso de normas penais, há também o dever que o Brasil adquiriu ao se submeter a organismos internacionais como a ONU e a OEA - os quais, como já dito, expressamente afirmam ser dever dos Estados-membros a punição desse tipo de violência específica pela adoção de normas e procedimentos próprios (tendo, inclusive, como proponente de tais normas, a República Federativa do Brasil, junto com outras nações). De forma que, ao menos aqui, não se pode falar em "reserva legal” e nem mesmo em “silêncio eloquente”, uma vez que há uma omissão objetiva, clara e que impõe solução urgente por parte do Estado brasileiro ${ }^{46}$.

A contemplação da possibilidade de omissão inconstitucional atende a um só tempo à exigência da obrigatoriedade de que o legislador e o Poder Executivo cumpram a Constituição em sua plenitude e à necessidade de mecanismo para se evitar que forças contramajoritárias simplesmente deixem de cumprir as determinações constitucionais mediante a inércia. Nessa medida é que se deve compreender o processo de reconhecimento de omissão inconstitucional não como uma simples exigência formal de concretizar normas, mas sim como um meio destinado à proteção das minorias políticas que se veem alijadas de direitos, os quais deveriam ter sido implantados pelo debate legislativo, ante a inexistência de espaço para o debate de tais direitos.

\footnotetext{
${ }^{45}$ Precisamos entender que, ao menos desde a Teoria Estruturante de Friedrich Müller, norma constitucional não pode ser entendida como texto constitucional, mas como o resultado da interpretação, como a concretização do programa e do âmbito da norma (MÜLLER, 2010, p. 54 et seq.)

46 Para uma discussão acerca da ideia de "silêncio eloquente", ver o Parecer da AGU a respeito das uniões homoafetivas, cujos argumentos podem se aplicar aqui (BRASIL. Advocacia Geral da União. Parecer $n$. 38/2009/RM/DENOR/CGU/AGU. 2009. Processo n. 00407.006409/2009-11. Disponível em: <http://www.agu.gov.br/page/download/index/id/3322930>. Acesso em: 13 jul. 2014).
} 
Não é outro o entendimento esposado por Lenio Streck:

Dito de outro modo, foi para evitar que o legislador ordinário e o Poder Executivo descumprissem os direitos previstos no pacto constituinte que foi elaborada essa fórmula de inconstitucionalidade do não fazer. Para ser mais claro, se na tradição liberal a inconstitucionalidade tem uma feição de simples retirada do mundo jurídico de textos incompatíveis com a Constituição, o advento do Estado Social de Direito e seu sucedâneo, o Estado Democrático de Direito, proporciona o surgimento de um outro tipo de inconstitucionalidade, aquele proveniente da inércia dos poderes públicos. Trata-se de um mecanismo que corre paralelo ao princípio que contrapõe o texto constitucional contra maiorias eventuais, indo, entretanto, mais longe: em vez de servir de defesa contra investidas de maiorias parlamentárias eventuais ou não, a inconstitucionalidade por omissão tem a função de compelir o Poder Executivo e instar o legislador a fazer aquilo que, embora estipulado no texto da Constituição, não deseja fazer, de forma total ou parcial (STRECK, 2013, p. 891).

\section{CONCLUSÕES}

Tem-se que o ponto central da criminalização da homofobia e da transfobia é a existência de normas que determinam ao Poder Legislativo a criminalização de condutas discriminatórias contra as minorias de orientação sexual distinta da orientação heteroafetiva dominante. Tal norma constitucional pode ser extraída da regra insculpida no art. 5º XLII da CF/88 (combinado com outros como o art. $1^{\circ}$, III, o art. $3^{\circ}$, IV, e o art. $5^{\circ}, \S 2^{\circ}$, todos da CF/88) que estipula um mandado de criminalização contra práticas racistas, considerando-se, nos termos do julgamento do HC 82.424, que racismo é sempre um conceito político-social de superioridade de um grupo sobre outro. Vale asseverar que a incorporação de mandados de criminalização na Constituição Federal refletem deveres de proteção com escopo jurídico-penal de direitos consagrados como essenciais.

A norma constitucional que impele a criminalização de atitudes discriminatórias contra indivíduos que se orientam de forma sexualmente diferente também se extrai do texto constitucional do art. 50 XLI, que determina a repressão por parte do Estado, por meio da utilização do direito penal, civil e administrativo, de toda e qualquer conduta discriminatória atentatória aos direitos e liberdades fundamentais. Não há qualquer dúvida que o conteúdo do direito à liberdade implica a possibilidade de o indivíduo ter orientação sexual diversa da orientação sexual da maioria. Qualquer conduta discriminatória que seja motivada pela orientação sexual merece a reprimenda por parte do Estado, seja de ordem criminal, civil, administrativa ou trabalhista, pelo imperativo de que nossa comunidade política deve ser fundada na consideração de indivíduos livres e iguais.

Portanto, parece-nos que há normas constitucionais bem claras que impõem ao Poder Legislativo a obrigação de utilizar-se do arcabouço jurídico-penal para criminalizar condutas discriminatórias contra a minoria, cuja orientação sexual é diversa, e contra a identidade de gênero. A questão, então, é quando se considerar que fica caracterizada a omissão inconstitucional. 
Se, no fundo, estamos falando acerca de direitos de igualdade e de liberdade em uma simbiose material no conteúdo de ambos os direitos, então devemos considerar que são direitos fundamentais e que, bem por isso, devem ter aplicabilidade imediata, consoante a prescrição que confere força normativa especial às normas fundamentais do art. $5^{\circ}, \S 1^{\circ}$ da $C F / 88$. Aplicabilidade imediata das normas constitucionais significa dizer que, mesmo não sendo possível o gozo e a fruição imediata de alguns direitos fundamentais, uma vez que dependem, por vezes, de interposição legisladora, a norma contida no art. $5^{\circ}, \S 1^{\circ}$ da CF/88 sustenta um dever geral, por parte dos órgãos estatais, de máxima eficácia e efetividade no sentido de que o direito fundamental não poderá ficar à mercê da vontade dos Poderes Públicos.

Nessa medida, exceto se entendermos que a norma que confere aplicabilidade imediata a todos os direitos fundamentais encontra-se revogada ou extirpada da Constituição, a omissão quanto ao dever de criminalização da homofobia e da transfobia ocorre desde há, pelo menos, poucos anos após a promulgação da Constituição que, frise-se, ocorreu há mais de 25 (vinte e cinco) anos.

Apenas para ilustrarmos o alto grau de omissão em que se encontra o Estado brasileiro quanto à criminalização das condutas discriminatórias em face das minorias de orientação sexual diversa e de identidade de gênero, durante os mais de 25 (vinte e cinco) anos de vigência da Constituição Federal assistimos à edição de leis que criminalizam as condutas discriminatórias em face de minorias, tais como preconceito de cor, etnia, religião (Lei 7.716/89), proteção ao trabalho de mulheres grávidas (Lei 9.029/95), proteção aos idosos (Lei 10.741/02), a Lei Maria da Penha e a lei contra a discriminação de portadores do vírus HIV (Lei 12.984/2014).

Decorre daí que a criminalização da discriminação de atos homofóbicos ou transfóbicos só não ocorreu por uma má vontade política-institucional do Poder Legislativo, que simplesmente não quer discutir e debater medidas legislativas que punam e reprimam tais condutas.

\section{REFERÊNCIAS}

ACKERMAN, Bruce. Nós, o povo soberano. Belo Horizonte: Del Rey, 2006.

AMBROSE, Tom. Heróis e Exílios: ícones gays através dos tempos. Belo Horizonte: Gutenberg, 2011.

BAHIA, Alexandre Melo Franco. A interpretação jurídica no Estado democrático de Direito: contribuição a partir da teoria do discurso de Jürgen Habermas. In: CATTONI DE OLIVEIRA, Marcelo A. (Coord.). Jurisdição e hermenêutica constitucional. Belo Horizonte: Mandamentos, 2004. 
Anti-Semitismo, Tolerância e Valores: anotações sobre o papel do Judiciário e a questão da intolerância a partir do voto do Ministro Celso de Mello no HC 82.424. Revista dos Tribunais, São Paulo, v. 847, p. 443-70, maio 2006.

A não-discriminação como direito fundamental e as redes municipais de proteção a minorias sexuais - LGBT. Revista de informação legislativa, v. 47, n. 186, p. 89-106, abr.jun. 2010.

. Homofobia no Brasil, resoluções internacionais e a Constituição de 1988. Revista Jus Navigandi, Teresina, ano 17, n. 3269, 13 jun. 2012. Disponível em: $<$ http://jus.com.br/artigos/21999>. Acesso em: 13 jul. 2014.

Proteção à Minoria LGBT no Brasil: avanços e desafios. In: JUBILUT, Liliana L.; BAHIA, Alexandre; MAGALHÃES, José L. Quadros de. Direito à diferença. Volume 2: Aspectos de proteção específica às minorias e aos grupos vulneráveis. São Paulo: Saraiva, 2013a.

. A Igualdade é Colorida: por uma nova compreensão do direito de igualdade que reconheça o direito à diversidade. In: ALVES, Cândice Lisbôa; MARCONDES, Thereza Cristina Bohlen Bitencourt (Org.). Liberdade, Igualdade e Fraternidade: 25 anos da Constituição Brasileira. Belo Horizonte: D'Plácido, 2013b.

. Fundamentos de teoria da constituição: a dinâmica constitucional no Estado Democrático de Direito brasileiro. In: FIGUEIREDO, Eduardo Henrique Lopes (et. al) (Org.). Constitucionalismo e democracia. Rio de Janeiro: Elsevier, 2012.

; MORAES, Daniel. Discriminação contra minorias sexuais, religião e o constitucionalismo brasileiro pós-88. Revista General de Derecho Constitucional, v. 10, p. 409-31, outubro 2010.

; NUNES, Dierle. O potencial transformador dos direitos privados no constitucionalismo pós-88. Revista dos Tribunais, São Paulo, v. 882, p. 45-60, abr. 2009.

BORRILLO, Daniel. Homofobia: história e crítica de um preconceito. Belo Horizonte: Autêntica Editora, 2010.

BORTOLINI, Alexandre (Coord.). Diversidade Sexual na Escola. Rio de Janeiro: Pró-Reitoria de Extensão/UFRJ, 2008.

BRASIL. Advocacia Geral da União. Parecer n. 38/2009/RM/DENOR/CGU/AGU. 2009. Processo n. 00407.006409/2009-11. Disponível em: <http://www.agu.gov.br/page/download/index/id /3322930>. Acesso em: 13 jul. 2014.

BRASIL. SEDH. Número de denúncias de violência homofóbica cresceu 166\% em 2012, diz relatório. 2013a. Disponível em: <http://www.sdh.gov.br/noticias/2013/junho/numero-dedenuncias-de-violencia-homofobica-cresceu-166-em-2012-diz-relatorio>. Acesso em: 13 jul. 2014.

. Relatório sobre violência homofóbica no Brasil: o ano de 2011. Brasília, 2012. Disponível em: <http://www.sedh.gov.br/brasilsem/relatorio-sobre-violencia-homofobica-no-brasil-o-ano-de2011/Relatorio\%20LGBT\%20COMPLETO.pdf>. Acesso em: 13 jul. 2014. 
. Relatório sobre violência homofóbica no Brasil: o ano de 2012. Brasília, 2013b. Disponível em: <http://www.sdh.gov.br/assuntos/lgbt/pdf/relatorio-violencia-homofobica-ano-2012>. Acesso em: 13 jul. 2014.

CANOTILHO, J.J. Gomes. Direito Constitucional e Teoria da Constituição. $7^{\mathrm{a}}$ ed. Coimbra: Almedina, 2003.

CARBONELL, Miguel. Consideraciones sobre La Ley Federal para Prevenir y Eliminar la Discriminación. In: DE LA TORRE MARTÍNEZ, Carlos. Derecho a la No Discriminación. México: UNAM, 2006.

CARVALHO NETTO, Menelick de. A Contribuição do Direito Administrativo Enfocado da Ótica do Administrado para uma Reflexão acerca dos Fundamentos do Controle de Constitucionalidade das Leis no Brasil: um pequeno exercício de Teoria da Constituição. Revista Fórum Administrativo, Belo Horizonte, n. 1, março 2001, p. 11-20.

. A Constituição da Europa. In: SAMPAIO, José Adércio Leite (Coord.). Crise e Desafios da Constituição: perspectivas críticas da teoria e das práticas constitucionais brasileiras. Belo Horizonte: Del Rey, 2003.

CATTONI DE OLIVEIRA, Marcelo de Andrade. Direito Processual Constitucional. Belo Horizonte: Mandamentos, 2001.

CRUZ, Álvaro Ricardo de Souza. Poder Constituinte e patriotismo constitucional. Revista Argumenta, n. 8, jan./jun. 2008, p. 9-56.

CURI, Ivan Guerios; NUNES, Dierle José Coelho; BAHIA, Alexandre Gustavo Melo Franco. Processo Constitucional Contemporâneo. Boletim da Faculdade de Direito - Universidade de Coimbra, v. LXXXV, p. 343-74, 2009.

HABERMAS, Jürgen. A inclusão do outro. São Paulo: Loyola, 2002.

. Era das transições. Rio de Janeiro: Tempo Brasileiro, 2003.

Facticidad y Validez: sobre el derecho y el estado democrático de derecho en términos de teoría del discurso. Madrid: Trotta, 1998.

O Estado-Nação europeu frente aos desafios da globalização: o passado e o futuro da soberania e da cidadania. Revista Novos Estudos CEBRAP, n. 43, p. 87-101, nov. 1995.

. Soberania Popular como procedimento: um conceito normativo de espaço público. Revista Novos Estudos CEBRAP, n. 26, p. 100-13, mar. 1990.

. Uma Conversa sobre Questões de Teoria Política. Entrevista a Mikael Carlehedem e René Gabriels. Revista Novos Estudos CEBRAP, n. 47, mar. 1997.

HONNETH, Axel. Luta por reconhecimento: a gramática dos conflitos sociais. São Paulo: Editora 34, 2003. 
JINKINGS, Daniella. A cada 36 horas, um homossexual é morto no Brasil. Agência Brasil, Brasília, 4 de abril de 2011. Disponível em: <http://agenciabrasil.ebc.com.br/noticia/2011-0404/cada-36-horas-um-homossexual-e-morto-no-brasil>. Acesso em: 13 jul. 2014.

MORAIS, Carlos Blanco. Justiça constitucional: garantia da Constituição e controlo da constitucionalidade. Tomo I. $2^{\text {a }}$ ed. Coimbra: Coimbra Editora, 2006.

MOTT, Luiz. Causa Mortis: Homofobia - Violação dos Direitos Humanos e Assassinato de Homossexuais no Brasil, 2000. Disponível em: <http://www.dhnet.org.br/dados/livros/dht/ br/mott_homofob/index.html>. Acesso em: 27 maio 2014.

MOUFFE, Chantal. Pensando a democracia moderna com e contra Carl Schmitt. Cadernos da Escola do Legislativo, Belo Horizonte, n. 2, p. 9-20, jul./dez. 1994. Disponível em: <www.alemg.gov.br/CadernosEscol/Caderno2/teoria.pdf>. Acesso em: 10 set. 2014.

MÜLLER, Friedrich. Metodologia do Direito Constitucional. 4 ${ }^{\text {a }}$ Ed. São Paulo: Editora Revista dos Tribunais, 2010.

NUCCI, Guilherme de Souza. Leis Penais e Processuais Penais Comentadas. Vol. I. 6 a ed., rev. e atualiz. São Paulo: Revista dos Tribunais, 2012.

OTTOSSON, Daniel. Uma pesquisa mundial sobre legislações que proíbem relações sexuais consensuais entre adultos do mesmo sexo. ILGA - Associação Internacional de Gays e Lésbicas. Homofobia do Estado, maio de 2008. Disponível em: <www.ilga.org>. Acesso em: 2 mar. 2014.

PIOVESAN, Flávia. Proteção judicial contra omissões legislativas. 2a Ed. São Paulo: Editora Revista dos Tribunais, 2003.

RIOS, Roger Raupp. A homossexualidade e a discriminação por orientação sexual no direito brasileiro. Revista de Informação Legislativa, a. 38 n. 149 jan./mar. 2001.

SANTOS, Boaventura de Sousa. Por uma concepção multicultural de direitos humanos. In: SANTOS, Boaventura de Sousa (Org.). Reconhecer para libertar: os caminhos do cosmopolitismo cultural. Rio de Janeiro: Civilização Brasileira, 2003.

STRECK, Lenio L. O Que é Isto - Decido Conforme Minha Consciência? Porto Alegre: Livraria do Advogado, 2010.

Jurisdição constitucional e decisão jurídica. $3^{\mathrm{a}}$ ed. São Paulo: Editora Revista dos Tribunais, 2013.

VIANA, Thiago G. A inefetividade da Lei Caó: uma tragédia anunciada? In: CRUZ, André Gonzalez (Org.). Direito criminal contemporâneo. Brasília: Kiron, 2012. 
THE NEED FOR CRIMINALIZING HOMOPHOBIA IN BRAZIL: DEMOCRATIC FUTURE AND INCLUSION OF MINORITIES

ABSTRACT: This article aims to address the issue of criminalization of homophobia, especially through the reflection on the Direct Action of Unconstitutionality by Omission \# 26 and the Writ of Injunction \# 4733, both filed before the Brazilian Supreme Court (STF) and wishing to urge this Court to declare the omissive condition in which is the Brazilian State towards minorities lesbians, gays, bisexuals, travestis, transsexuals and transgenders (LGBT) - regarding the criminalization of discriminatory behaviors that threaten their rights to freedom and equality. Therefore, we demonstrate that the constitutional project is not and should not be seen as a closed project to new subjects and new rights - the process of constitutional learning and democratic consolidation should seek the incorporation of new subjects who, at some point, suffer discrimination.

KEYWORDS: Brazilian Supreme Court. Criminalization. Democracy. Homophobia. Unconstitutional omission. 